УдК 54.056:54.03:577.127.3

\title{
ОПТИМИЗАЦИЯ УСЛОВИЙ ВЫДЕЛЕНИЯ ХЛОРОФИЛЛОВ ИЗ КРАПИВЫ ДВУДОМНОЙ (URTICA DIOICA L.) И СПИРУЛИНЫ (SPIRULINA PLATENSIS)
}

\author{
() Д.Р. Каримов ${ }^{1,2}$, В.В. Макаров ${ }^{3}$, С.О. Кручин ${ }^{3}$, Д.Б. Березин ${ }^{3 *}$, Н.Л. Смирнова ${ }^{1}$, М.Б. Березин ${ }^{1}$, \\ Е.И. Желтова ${ }^{2}$, А.И. Стрельников ${ }^{2}$, А.В. Кустов ${ }^{1,2}$ \\ ${ }^{1}$ Институт химии растворов им. Г.А. Крестова РАН, ул. Академическая, 1, \\ Иваново (Россия) \\ ${ }^{2}$ Ивановская государственная медицинская академия Минздрава России, \\ Шереметевский пр-m, 8, Иваново (Россия) \\ ${ }^{3}$ Ивановский государственный химико-технологический университет, НИи \\ макрогетероциклических соединений, Шереметевский пр-m, 7, Иваново \\ (Россия), e-mail: berezin@isuct.ru
}

В работе рассмотрены и сопоставлены различные факторы, влияющие на эффективность экстрактивного выделения хлорофиллов из двух растительных источников - цветкового растения крапивы двудомной (Urtica dioica L.), содержащего смесь хлорофиллов $a$ и $b$, и сине-зеленой водоросли спирулины (Spirulina platensis), содержащей хлорофилл $a$. Предпочтительным растворителем для экстракции хлорофилла из спирулины является этанол, а из крапивы ацетон. Обработка сырья ультразвуком, перемешивание, предварительная криообработка биомассы повышают выход хлорофиллов, а сочетание таких факторов приводит к существенному увеличению выхода продуктов. Криообработка сырья оказывает положительное влияние на выход пигментов только при экстракции ацетоном.

Ключевые слова: хлорофиллы, экстракция, крапива двудомная (Urtica dioica L.), сине-зеленая водоросль спирулина (Spirulina platensis), ультразвуковая обработка, криообработка сырья жидким азотом.

Работа поддержана грантом РФФИ (проект №13-03-00557a).

\section{Введение}

Хлорофиллы являются одними из наиболее распространенных природных пигментов, ежегодное воспроизводство которого в растительной биомассе составляет $10^{12}-10^{14}$ тонн в год [1-4]. На основе хлорофиллового сырья возможно создание производства важных лекарственных препаратов, пищевых красителей, катализаторов, фотопреобразователей энергии [5-7]. В связи с общим развитием биотехнологии, и в частности возрастанием интереса к применению малотоксичных пигментов природного происхождения, разработка эффектив-

Каримов Дмитрий Рустамович - кандидат химических наук, научный сотрудник

Макаров Владимир Владимирович - студент

Кручин Сергей Олегович - студент

Березин Дмитрий Борисович - доктор химических наук, профессор кафедры органической химии,

e-mail: berezin@ isuct.ru

Смирнова Наталья Леонидовна - кандидат химических наук, научный сотрудник

Березин Михаил Борисович - доктор химических наук, профессор, ведущий научный сотрудник

Желтова Е.И. - студентка

Стррельников Александр Игоревич - доктор медицинских наук, профессор, проректор

Кустов Андрей Владимирович - доктор химических наук, старший научный сотрудник ных методов выделения хлорофиллов, их химическая модификация, а также поиск новых областей использования являются весьма перспективными [3-9].

В основе молекулы хлорофилла лежит магниевый комплекс хлорина ( $\beta$-дигидропорфирина, например, соед. I-II), содержащий дополнительное изоциклическое циклопентанонное кольцо V и остаток пропионовой кислоты в кольце IV, этерифицированный фитолом $\left(\mathrm{C}_{20} \mathrm{H}_{39} \mathrm{OH}\right)$, а также метильные и винильную группы в замещаемых положениях макроцикла. Наиболее распространенные в растительном мире хлорофиллы $a$ (соед. I) и $b$ (соед. II) различаются лишь заместителем R в положении 7 (рис. 1).

\footnotetext{
* Автор, с которым следует вести переписку.
} 


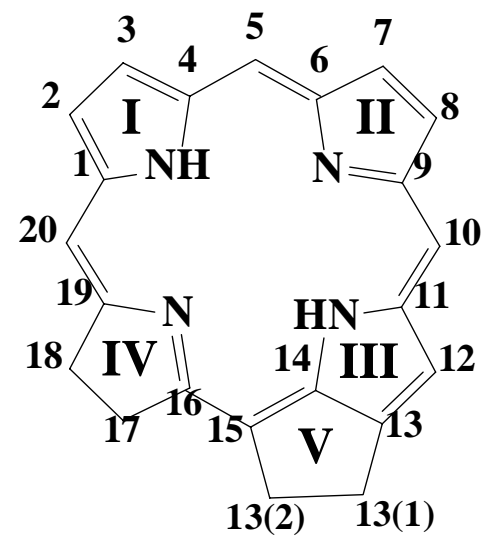

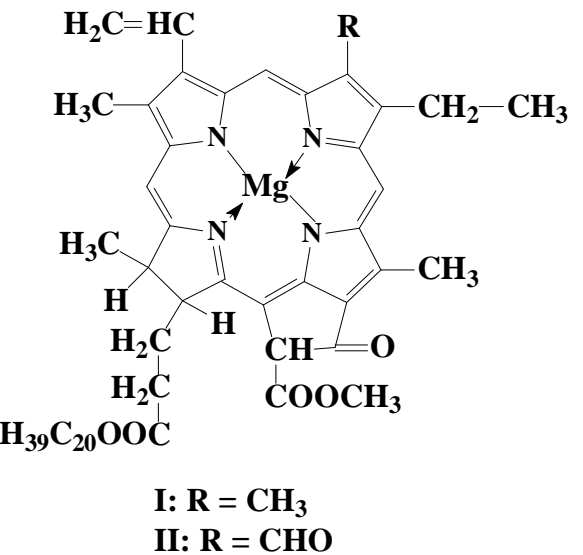

Рис. 1. Нумерация фрагментов макроцикла хлорофиллов

Наиболее распространенным способом выделения хлорофиллов из природных источников является экстракция [5, 10-15]. При этом выбор растворителя и дополнительных условий, таких как время обработки, температурный режим на предварительном этапе и во время экстракции, добавление электролита, воздействие ультразвука, могут играть важную роль в оптимизации выхода целевого продукта.

Имеется большое число работ по выделению хлорофиллов из крапивы двудомной (Urtica dioica) [5, 12]. Однако крапива, подобно другим высшим растениям, содержит смесь хлорофиллов $a$ и $b$, разделение которой на компоненты весьма трудоемко. Сине-зеленые водоросли, в частности спирулина (Spirulina platensis), содержат только хлорофилл $a$ и являются перспективными источниками его получения. Обычно содержание хлорофиллов в экстракте в расчете на сухой вес высшего растения или водоросли составляет от 0,5 до $1,5 \%$ [5, 10].

Для экстракции зеленых пигментов из свежего растительного сырья используются различные индивидуальные, смешивающиеся с водой растворители - спирты, ацетон, N,N-диметилформамид, а также смешанные - этилацетат-гексан, этанол-петролейный эфир и другие среды $[5,10,11]$. Одним из самых распространенных экстрагентов является абсолютизированный или водный ацетон $\left(\mathrm{Me}_{2} \mathrm{CO}\right)[5,12,13]$. Ацетоновый раствор с концентрацией воды больше $10 \%$ неполно экстрагирует малополярный хлорофилл $a$ из высших растений. Однако добавление небольших количеств воды к растворителям $\left(\mathrm{Me}{ }_{2} \mathrm{CO}, \mathrm{EtOH}\right)$ улучшает их экстрагирующую способность, поскольку вода нарушает электролитный баланс в хлоропластах, вызывая разрушение хлорофилловых агрегатов [16, 17], а также уменьшает растворимость липидных соединений, таких как каротиноиды [18].

Ацетон применяют и для получения хлорофиллового экстракта из Spirulina [10, 19]. В ацетоне хлорофиллы устойчивы, однако он является менее эффективным экстрагентом свежего растительного сырья по сравнению с низшими спиртами, где, тем не менее, возможна их алломеризация, в частности окисление С-Н связи в 13(2)-положении до С-OH [10]. Алломеризация может происходить при длительной экстракции, а также при хроматографировании.

Важное значение для эффективной экстракции имеет выбор соотношения объема растворителя и растительного сырья: для свежей биомассы - это $20 \div 1-30 \div 1$, в случае высушенного сырья соблюдают отношение $5 \div 1[10]$.

Для удаления хлорофиллов из растительной ткани целесообразно провести предварительное измельчение биомассы [10]. Следом за измельчением в избытке растворителя смесь фильтруют или центрифугируют для отделения твердого вещества от экстракта, при неполном извлечении экстракцию повторяют [13].

С целью повышения эффективности экстракции иногда проводят предварительную обработку растительного сырья небольшим количеством спирта или ацетона для удаления избытка воды и/или гликопротеидов, окружающих клеточную стенку [20]. При экстракции пигментов из растений с кислой цитоплазмой, например из крапивы, для предотвращения образования феофитинов добавляют бикарбонат или карбонат натрия, N,N-диметиланилин или гидроксид аммония [10, 12]. B работе [21] Spirulina перед экстракцией ацетоном отмывалась от водорастворимых веществ фосфатным буфером с $\mathrm{pH}=6$. Такая процедура облегчает в дальнейшем проницаемость клеточных стенок для растворителя. Кроме того, проницаемость оболочек клеток можно повысить, используя замораживание-размораживание растительного сырья $[19,22]$ или обработку ультразвуком [10]. 
Некоторые растительные материалы перед измельчением рекомендуют кратковременно нагревать в кипящей воде (1-2 мин) с последующим резким охлаждением ледяной водой, чтобы улучшить экстрагируемость и уменьшить ферментативное окисление и гидролиз. В то же время известно, что нагревание вызывает изомеризацию хлорофиллов и их частичное разложение [10]. Способность пигментов экстрагироваться зависит от проницаемости клеточной стенки и изменяется в зависимости от содержания воды. Более полно экстракция из высушенных листьев происходит с применением предварительной гидратации [10]. Кроме того, экстракция хлорофилла увеличивается по мере увеличения полярности растворителя.

В настоящей работе изучено влияние различных факторов - природы растворителя, температуры, ультразвуковой обработки, перемешивания, а также их сочетания - на степень извлечения хлорофиллов из растительного сырья.

\section{Экспериментальная часть}

В работе использовались образцы хлорофиллов, полученные из двух растительных источников: крапивы двудомной (Urtica dioica L.) и сине-зеленой водоросли спирулины (Spirulina platensis). В случае крапивы смесь хлорофиллов $a$ и $b$ выделялась из высушенных в темноте и измельченных листьев растения, собранных в мае, до начала цветения. Место сбора образцов - Иваново, в городской черте. Спирулина использовалась в виде высушенной массы, поставляемой в одном случае из Китая, в другом - из Германии. В качестве растворителей для экстракции использовались 96\%-й этанол и ацетон марки «Ч». Основная методика экстракции заключалась в следующем:

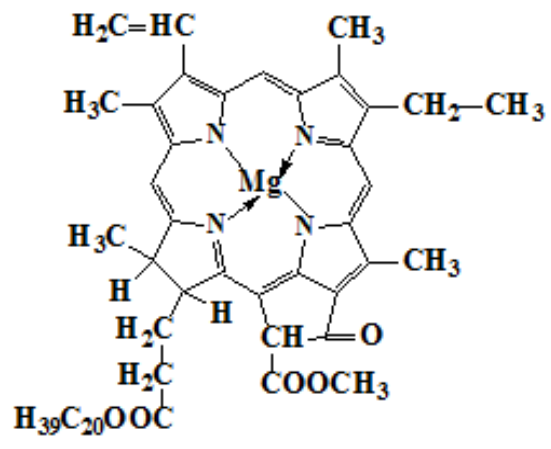

I

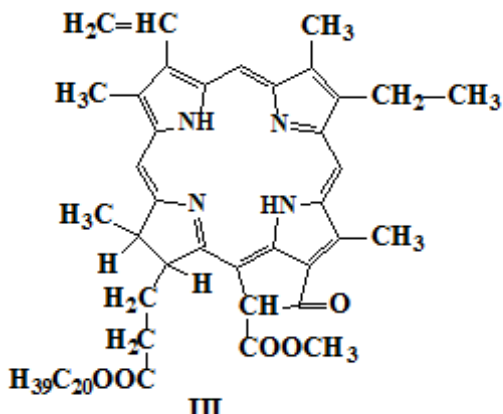

III
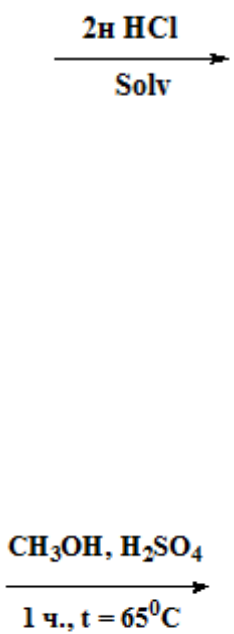

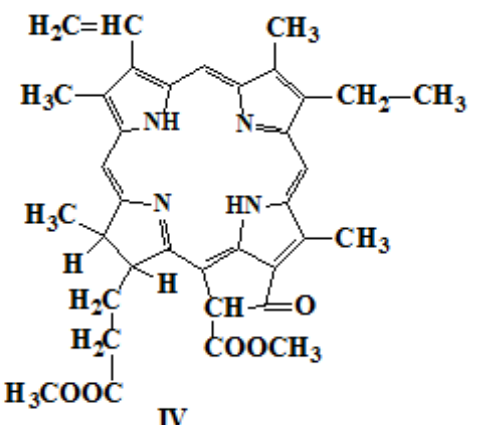

50 г сухого измельченного растительного сырья заливали 250 мл 96\%-го раствора этилового спирта $[5,11]$ или ацетона $[12,13]$ и экстрагировали в течение часа при температуре $50{ }^{\circ} \mathrm{C}$ и постоянном перемешивании на ротационном испарителе или с помощью механической мешалки без доступа света (см. таблицу). Затем полученный экстракт фильтровали на воронке Бюхнера, фильтрат подкисляли $36 \%$-й $\mathrm{HCl}$ до получения 2н раствора. Далее спиртовой экстракт оставляли на 12 ч в морозильной камере. Полученный спиртовой раствор с осадком феофитина $a$ (соед. III) (1) фильтровали на фильтре Шотта, остаток сушили под вакуумом и взвешивали. При использовании ацетона в качестве экстрагента подкисленный $\mathrm{HCl}$ ацетоновый экстракт хлорофилловых пигментов упаривали на ротационном испарителе до вязкой зеленой массы, отмывали водой от ацетона и кислоты, экстрагировали в дихлорметан, раствор концентрировали и про- 
водили колоночную хроматографию на оксиде алюминия V степени активности по Брокману с использованием дихлорметана в качестве элюента. Затем феофитин $a$ (соед. III) или смесь пигментов $(a+b)$ перерабатывались на метилфеофорбид $a$ (соед. IV, (2)) (или смесь $a+b$ производных) путем кипячения с 5\%ным (об.) раствором серной кислоты в метаноле в течение 1ч (2) с последующим осаждением продукта в ходе разбавления реакционной массы водой $1: 1$ и ее охлаждения в течение 12 ч в морозильной камере. Более высокая степень кристалличности метилфеофорбидов по сравнению с феофитинами благоприятствует определению выхода модифицированного продукта экстракции с более высокой точностью (табл.). Выход феофитина $a$ (или смеси $a+b$ ) определялся только в некоторых случаях (табл.). Чистоту соединений оценивали с помощью ТСХ, электронной спектроскопии (ЭСП) и спектроскопии протонного магнитного резонанса $\left({ }^{1} \mathrm{H}\right.$ ЯМР).

В серии последующих экспериментов модифицировали условия экстракции следующим образом (табл.):

1. Влажную зеленую массу подвергали замораживанию в морозильной камере холодильника в течение 12 ч, а затем экстрагировали 250 мл растворителя (этанол или ацетон) при перемешивании на ротационном испарителе и температуре $50{ }^{\circ} \mathrm{C}$.

2. Сухую массу помещали в тонкостенную пластиковую емкость, заливали 250 мл растворителя и подвергали действию ультразвука (рабочая частота 40 кГц; мощность - 70, 120 Вт) при температуре $50{ }^{\circ} \mathrm{C}$ без перемешивания.

3. Сухую массу помещали в тонкостенную пластиковую емкость, заливали 250 мл растворителя и подвергали действию ультразвука (рабочая частота 40 кГц; мощность - 70 Вт) при температуре $50{ }^{\circ} \mathrm{C}$ и постоянном перемешивании механической мешалкой.

4. Сухую массу помещали в тонкостенную пластиковую емкость, заливали 250 мл растворителя, обрабатывали жидким азотом и подвергали действию ультразвука (рабочая частота 40 кГц; мощность 70 Вт) при температуре $50{ }^{\circ} \mathrm{C}$ и постоянном перемешивании механической мешалкой.

Количественные результаты приведены в таблице и на рисунке 2.

\section{Обсуждение результатов}

Усовершенствование методики экстракции хлорофилловых производных, проводимой нами при перемешивании реакционной массы и нагревании ее до $50{ }^{\circ} \mathrm{C}$ в течение часа, предполагает повышение ее эффективности за счет ультразвукового воздействия с частотой 70-120 Вт, предварительного охлаждения реакционной массы жидким азотом, а также высаливания конечного продукта из раствора, варьирования типа растительного сырья и экстрагента.

Выход хлорофилла $a$ из сине-зеленой водоросли Spirulina, целевым образом химически модифицированного в ходе выделения до феофитина $a^{* *}(1)$, а затем - до диметилового сложного эфира феофорбида $\mathrm{a}^{* *}(2)$, зависит от марки продукта. Так, максимальный достигаемый выход метилфеофорбида $a$ из исходного сухого растительного сырья изменяется при экстракции этанолом от 0,84\% до 1,28\%, т.е. возрастает на 0,44\% при замене Spirulina производства Китая на продукт, приобретенный в Германии (табл.).

Преимуществом спирта как экстрагента по сравнению с ацетоном является возможность высаждения из него хлорофилловых производных путем подкисления реакционной массы и выдерживания ее при пониженной температуре в течение 0,5-3 суток (см. экспериментальную часть). Для того чтобы хлорофилловые продукты осаждались и выделялись из реакционной массы с высоким выходом, содержание воды в исходном спирте не должно быть слишком высоким. Так, при содержании воды в системе 30 и более процентов хлорофилловые производные в осадок не выпадают, поскольку их концентрация в растворе в результате слабой степени экстракции сильно снижается. 50 г водоросли Spirulina при набухании поглощает до 130 мл воды. По этой причине пришлось исключить из методики фактор предварительного запаривания сухой биомассы в воде при $50{ }^{\circ} \mathrm{C}$. Из ацетоновых растворов хлорофиллы обычно не выпадают, кроме как при действии на эти растворы фосфатного буфера [21], поэтому для выделения из реакционной массы чистых индивидуальных пигментов в этом случае обычно необходима стадия хроматографической очистки, снижающая выход целевого продукта и приводящая к существенному удорожанию стадии экстракции. Применение метода высаливания хлорофиллов из раствора $\mathrm{NaCl}, \mathrm{CH}_{3} \mathrm{COONa},\left[\mathrm{N}(\mathrm{R})_{4}\right] \mathrm{Br}\left(\mathrm{R}=\mathrm{C}_{6} \mathrm{H}_{13}-, \mathrm{C}_{8} \mathrm{H}_{17}-\right)$ не способствовало осаждению по причине недостаточной растворимости рассматриваемых солей в ацетоне.

\footnotetext{
** Или смеси продуктов $(a+b)$ при использовании крапивы в качестве растительного сырья.
} 


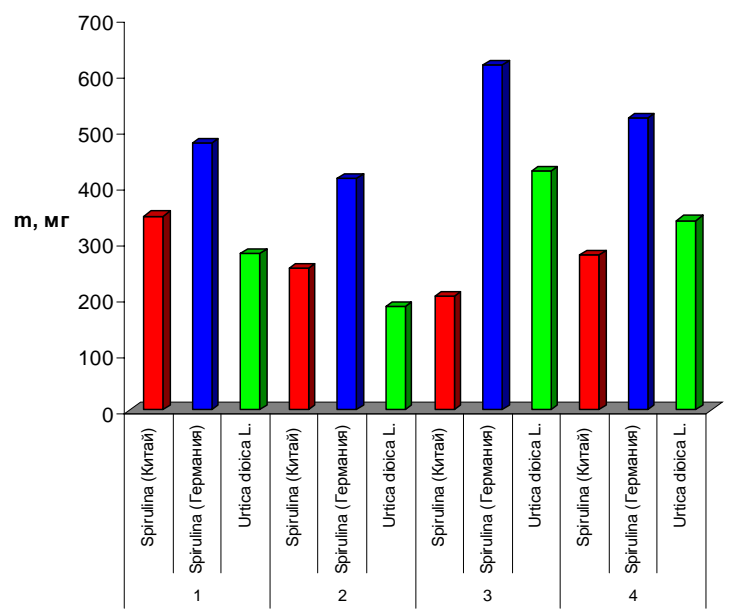

a)

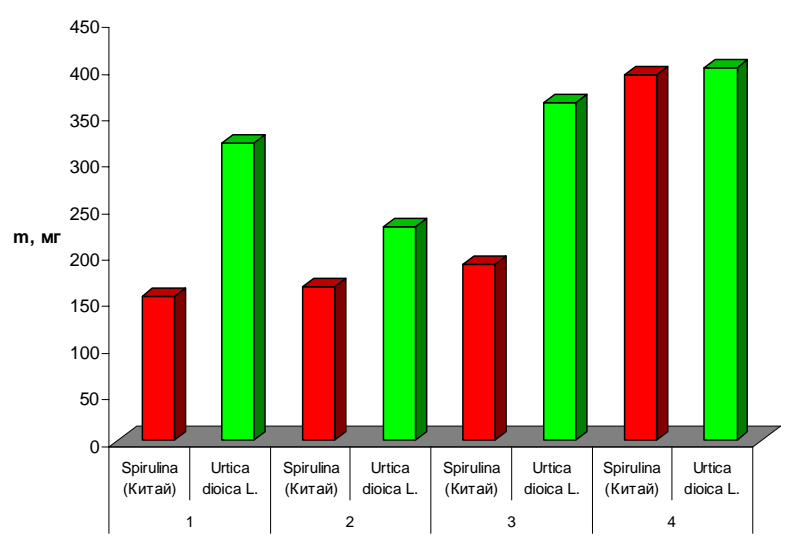

б)

Рис. 2. Выход экстракции хлорофилловых пигментов из растительного сырья в пересчете на метилфеофорбиды (соед. IV): а) в этаноле; б) в ацетоне под действием внешних факторов:

1 - перемешивание; 2 - ультразвук (УЗ); 3 - перемешивание + У3; 4 - перемешивание + У3 + криообработка

Результаты экстракции и выходы модифицированных производных хлорофилла $a$ (или их смесей $a+b$ ) из экстрактов растительного сырья при $50{ }^{\circ} \mathrm{C}$

\begin{tabular}{|c|c|c|c|c|c|c|c|c|c|}
\hline \multirow[b]{2}{*}{ № } & \multirow[b]{2}{*}{$\begin{array}{l}\text { Растительное сырье } \\
\text { (50 г) }\end{array}$} & \multirow[b]{2}{*}{ 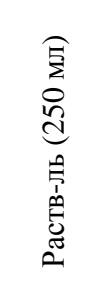 } & \multirow{2}{*}{ 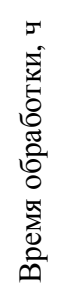 } & \multirow[b]{2}{*}{ 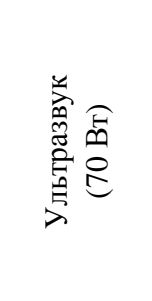 } & \multirow{2}{*}{ 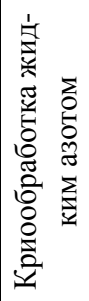 } & \multicolumn{2}{|c|}{ Перемешивание } & \multirow[b]{2}{*}{ 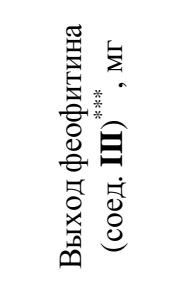 } & \multirow{2}{*}{ 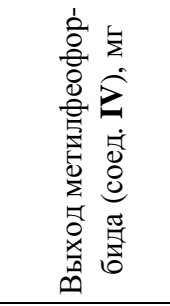 } \\
\hline & & & & & & 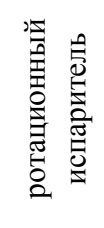 & 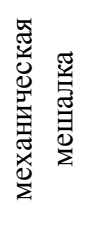 & & \\
\hline 1 & Spirulina (Китай) & $\mathrm{EtOH}$ & 1 & - & - & + & - & - & $347(0,69 \%)$ \\
\hline 2 & Spirulina (Китай) & $\mathrm{EtOH}$ & 1 & + & - & - & - & $283(0,57 \%)$ & $260(0,52 \%)$ \\
\hline 3 & Spirulina (Китай) & EtOH & 1 & $+(120 \mathrm{BT})$ & - & - & - & $350(0,70 \%)$ & $245(0,49 \%)$ \\
\hline 4 & Spirulina (Китай) & EtOH & 1 & + & - & - & + & $526(1,05 \%)$ & $422(0,84 \%)$ \\
\hline 5 & Spirulina (Китай) & $\mathrm{EtOH}$ & 2 & + & - & - & + & $276(0,55 \%)$ & $226(0,45 \%)$ \\
\hline 6 & Spirulina (Китай) & EtOH & 1 & + & + & - & + & - & $277(0,55 \%)$ \\
\hline 7 & Spirulina (Китай) & $\mathrm{Me}_{2} \mathrm{CO}$ & 1 & - & - & + & & - & $155(0,31 \%)$ \\
\hline 8 & Spirulina (Китай) & $\mathrm{Me}_{2} \mathrm{CO}$ & 1 & + & - & - & & - & $165(0,33 \%)$ \\
\hline 9 & Spirulina (Китай) & $\mathrm{Me}_{2} \mathrm{CO}$ & 1 & + & - & & + & - & $189(0,38 \%)$ \\
\hline 10 & Spirulina (Китай) & $\mathrm{Me}_{2} \mathrm{CO}$ & 1 & + & + & & + & - & $393(0,79 \%)$ \\
\hline 11 & Spirulina (Германия) & EtOH & 1 & + & - & & - & - & $415(0,83 \%)$ \\
\hline 12 & Spirulina (Германия) & $\mathrm{EtOH}$ & 1 & - & - & & + & - & $477(0,95 \%)$ \\
\hline 13 & Spirulina (Германия) & $\mathrm{EtOH}$ & 1 & + & - & & + & - & $617(1,23 \%)$ \\
\hline 14 & Spirulina (Германия) & $\mathrm{EtOH}$ & 1 & + & + & & + & - & $522(1,04 \%)$ \\
\hline 15 & $\begin{array}{l}\text { Urtica dioica L. } \\
\text { (свежее сырье) }\end{array}$ & EtOH & 1 & - & - & + & - & $425(0,85 \%)$ & $272(0,54 \%)$ \\
\hline 16 & $\begin{array}{l}\text { Urtica dioica } \mathrm{L} \text {. } \\
\text { (через } 2 \text { недели) }\end{array}$ & $\mathrm{EtOH}$ & 1 & - & - & + & - & $415(0,83 \%)$ & $282(0,56 \%)$ \\
\hline 17 & Urtica dioica $\mathrm{L}$. & EtOH & 1 & + & - & - & - & $273(0,55 \%)$ & $185(0,37 \%)$ \\
\hline 18 & Urtica dioica $\mathrm{L}$. & EtOH & 1 & - & - & - & + & $453(0,91 \%)$ & $286(0,57 \%)$ \\
\hline 19 & Urtica dioica $\mathrm{L}$. & EtOH & 1 & + & - & - & + & - & $427(0,85 \%)$ \\
\hline 20 & Urtica dioica $\mathrm{L}$. & $\mathrm{EtOH}$ & 1 & + & + & - & + & - & $339(0,68 \%)$ \\
\hline 21 & Urtica dioica $\mathrm{L}$. & $\mathrm{Me}_{2} \mathrm{CO}$ & 1 & - & - & & + & - & $319(0,64 \%)$ \\
\hline 22 & Urtica dioica $\mathrm{L}$. & $\mathrm{Me}_{2} \mathrm{CO}$ & 1 & + & - & & - & - & $229(0,46 \%)$ \\
\hline 23 & Urtica dioica $\mathrm{L}$. & $\mathrm{Me}_{2} \mathrm{CO}$ & 1 & + & - & & + & - & $363(0,73 \%)$ \\
\hline 24 & Urtica dioica $\mathrm{L}$. & $\mathrm{Me}_{2} \mathrm{CO}$ & 1 & + & + & & + & - & $401(0,80 \%)$ \\
\hline
\end{tabular}

\footnotetext{
*** Или смеси продуктов $(a+b)$ из U. dioica.
} 
Из 2 н этанольного раствора соляной кислоты феофитины полностью выпадают в осадок при использовании экстракта крапивы через 12 ч; в случае экстракции из спирулины дополнительное количество продукта (около 10\%) выпадает еще через 2,5 суток.

В ходе проведенных исследований установлено, что совместное действие нескольких факторов на выход экстракции всегда эффективнее действия каждого из них в отдельности (табл.). По эффективности при нагревании реакционной массы при $50{ }^{\circ} \mathrm{C}$ в течение 1 ч в зависимости от природы растворителя и сырья они располагаются следующим образом: ультразвук (выход $\eta_{0}$ ) < перемешивание реакционной массы на ротационном испарителе или на мешалке $\left(\eta_{0}+40-60 \%\right)<$ ультразвук + перемешивание $\left(\eta_{0}+50-62 \%\right)$ (табл., рис. 2).

Предварительная механическая обработка растительного сырья на примере крапивы, т.е. измельчение его при помощи шаровой мельницы непосредственно перед экстракцией и экстракция через 2 недели после измельчения дали одинаковые результаты (выход смеси метилфеофорбидов $a+b \quad 0,52-0,54 \%$ ) (табл.). Увеличение времени экстракции хлорофилла из Spirilina ацетоном приводит к снижению соед. IV практически вдвое, тогда как в случае ацетона такое время процесса признавалось оптимальным [13].

Нами показано, что предварительная обработка растительной массы жидким азотом увеличивает выход экстракции феофорбидов из ацетона (более чем вдвое в случае спирулины и на 10\% в случае крапивы) и не благоприятствует экстракции хлорофиллов спиртом - наблюдается снижение выхода на 35-65 и $9 \%$ соответственно (табл., рис. 2), что в настоящее время не находит объяснения.

При замене спирулины на крапиву выход пигментов в сравнимых условиях понижается в среде спирта приблизительно на 20-65\%, а в ацетоне - повышается вдвое.

\section{Bblводbl}

1. Спирулина более удобна для получения индивидуальных производных хлорофиллового ряда, поскольку содержит только хлорофилл $a$-ряда в отличие от крапивы и других высших растений, содержащих обычно смесь хлорофиллов $a$ и $b$. Содержание хлорофилла в спирулине существенно зависит от марки и страны-производителя.

2. Предпочтительным растворителем для экстракции хлорофилла из спирулины является этанол, а из крапивы - ацетон. Показано, что преимущества экстракции пигментов этанолом связаны с простотой реализации процесса, меньшими потерями продукта при очистке, а также с высокой экологичностью, что позволяет использовать полученный растительный жмых как пищевую биологически активную добавку в животноводстве.

3. Доказано, что применение дополнительных физических факторов - обработка сырья ультразвуком, перемешивание, предварительное замораживание биомассы жидким азотом с последующим размораживанием - повышает выход хлорофиллов, а сочетание нескольких таких факторов приводит к существенному увеличению выхода продуктов. Криообработка сырья оказывает положительное влияние на выход пигментов только при экстракции ацетоном. Наибольший выход пигмента в пересчете на метилфеофорбид IV имел место в случае экстракции из Spirulina этанолом при совместном действии перемешивания и ультразвука.

\section{Сиисок литературы}

1. Годнев Т.Н. Хлорофилл. Его строение и образование в растении. Минск, 1963. 319 с.

2. Рабинович Е. Фотосинтез. М., 1951. 648 с.

3. Березин Б.Д., Березин М.Б., Румянцева С.В. Синтез и применение экологически чистых металлосодержащих красителей на основе производных хлорофилла // Координационная химия. 2006. Т. 32. № 3. С. 235-239.

4. Березин Б.Д., Румянцева С.В., Морыганов А.П., Березин М.Б. Химические превращения хлорофилла и его использование для создания экологически чистых красителей нового поколения. // Успехи химии. 2004. Т. 73. № 2. С. 197-207.

5. Койфман О.И., Аскаров К.А., Березин Б.Д., Ениколопян Н.С. Порфирины. Структура. Свойства. Синтез. М., 1985. С. 175-204.

6. Павлов В.Ю., Пономарев Г.В. Пути модификации периферических заместителей хлорофиллов $a$ и $b$ и их производных // Химия гетероциклических соединений. 2004. № 4. С. 483-519.

7. Миронов А.Ф. Современное состояние химии фотосенсибилизаторов на основе природных порфиринов, хлоринов и бактериохлоринов // Успехи химии порфиринов. 2004. Т. 4. С. 271-288. 
8. Березин Б.Д. Координационные свойства и функции важнейших биопорфиринов // Известия вузов. Химия и химическая технология. 1984. Т. 27. В. 3. С. 259-271.

9. Cannon J., Cannon M. Dye plants and dyeing. London, 1994. 128 p.

10. Svec W.A. The isolation, preparation, characterization and estimation of the chlorophylls and bacteriochlorophylls // In book: The porphyrins. New-York: Acad. Press, 1978. Vol. 5. Pp. 342-400.

11. Белых Д.В. Новые подходы в синтезе полифункциональных хлоринов на основе хлорофилла $a$ : дисс. ... д-ра хим. наук. Иваново, 2012. 320 с.

12. Березин М.Б. Сольватация хлорофилла и родственных соединений: дисс. ... д-ра хим. наук. Иваново, 1993. $340 \mathrm{c}$.

13. Salgado A. Chlorin photosensitisers for tumor phototherapy. London, 1993. $168 \mathrm{p}$.

14. Ашмаров В.В., Баум Р.Ф., Мещерякова А.Л., Пономарев Г.В., Сухин Г.М. Промышленное производство Spirulina - реальный источник крупномасштабного получения фотосенсибилизаторов на основе хлорофилла $a$ // Тезисы VII Междунар. конф. по химии порф. и их аналогов. СПб., 1995. С. 151-152.

15. Рашидова С.Т. Переработка хлорофилла из выделений тутового шелкопряда на металлопорфирины и исследование их физико-химических свойств: дисс. ... канд. хим. наук. Иваново, 1983. 135 с.

16. Porra R.J. The assay of chlorophylls $a$ and $b$ converted to their respective magnesium-rhodochlorin derivatives by extraction from recalcitrant algal cells with aqueous alkaline methanol: prevention of allomerisation with reductants // Biochim. Biophys. Acta. 1990. Vol. 1015. N3. Pp. 493-502.

17. Humphrey A.M. Chlorophyll // Food Chem. 1980. Vol. 5. Pp. 57-67.

18. Bruinsma J. The quantitative analysis of chlorophylls a and b in plant extracts // Photochem. Photobiol. 1963. Vol. 2. Pp. 241-244.

19. Osuka A., Wada U., Shinoda S. Covalently linked pyropheophorbide dimers as model of the special pair in the photosynthetic reaction center // Tetrahedron. 1996. Vol. 52. N12. Pp. 4311-4326.

20. Holden M. Analytical methods - chlorophylls // Chemistry and biochemistry of plant pigments. Ed by Goodwin T.W. New-York, 1976. Vol. 2. 2nd ed. Pp. 1-27.

21. Borovcov V.V, Gribcov A.A., Kozyrev A.N., Brandis A.S., Ishida A., Sacata Y. Synthesis and properties of pheophorbide-quinone compounds // Bull. Chem. Soc. Japan. 1992. Vol. 65. Pp. 1533-1537.

22. Ma L., Dolphin D. Nucleophylic reaction of 1,8-diazabicyclo-[5,4,0]-undec-7-en and 1,5-diazabicyclo-[4,3,0]-non-5en] with methylpheophorbide $a$. Unexpected products // Tetrahedron. 1996. Vol. 52. N3. Pp. 849-860.

Поступило в редакиию 3 декабря 2013 г. 
Karimov D.R. ${ }^{1,2}$, Makarov V.V. ${ }^{3}$, Kruchin S.O. ${ }^{3}$, Berezin D.B. ${ }^{3 *}$, Smirnova N.L. ${ }^{1}$, Berezin M.B. ${ }^{1}$, Zheltova E.I. ${ }^{2}$, Strel'nikov A.I. ${ }^{2}$, Kustov A.V. ${ }^{1,2}$ OPTIMIZATION OF EXTRACTION CONDITIONS OF CHLOROPHYLLS A AND $B$ FROM URTICA DIOICA L. AND SPIRULINA PLATENSIS

${ }^{1}$ Institute of Solution Chemistry behalf G.A. Krestov Russian Academy of Sciences, st. Academic, 1, Ivanovo (Russia)

${ }^{2}$ Ivanovo State Medical Academy of the Ministry of Health of Russia, Sheremetevsky Ave., 8, Ivanovo (Russia)

${ }^{3}$ Ivanovo State University of Chemistry and Technology, Research Institute macroheterocyclic compounds,

Sheremetevsky Ave., 7, Ivanovo (Russia), e-mail: berezin@isuct.ru

Various factors as the nature of the solvent, temperature, presence or absence of stirring and sonication, affecting the efficiency of extractive separation of the two chlorophylls from two plant sources - a flowering plant of nettle (Urtica dioica L.), containing a mixture of chlorophyll a and b, and the blue-green alga spirulina (Spirulina platensis), containing only chlorophyll a, are compared in a paper. The aim of the work was to optimize the conditions for the allocation of chlorophyll from plant material.

Keywords: chlorophyll, extraction, nettle (Urtica dioica L.), blue-green algae Spirulina (Spirulina platensis), sonication, cryotreatment raw liquid nitrogen.

\section{References}

1. Godnev T.N. Hlorofill. Ego stroenie i obrazovanie v rastenii. [Chlorophyll. Its structure and formation in the plant]. Minsk, 1963, 319 p. (in Russ.)

2. Rabinovich E. Fotosintez. [Photosynthesis]. Moscow, 1951, 648 p. (in Russ.)

3. Berezin B.D., Berezin M.B., Rumjanceva S.V. Koordinacionnaja himija, 2006, vol. 32, no. 3, pp. 235-239. (in Russ.)

4. Berezin B.D., Rumjanceva S.V., Moryganov A.P., Berezin M.B. Uspehi himii, 2004, vol. 73, no. 2, pp. 197-207. (in Russ.)

5. Kojfman O.I., Askarov K.A., Berezin B.D., Enikolopjan N.S. Porfiriny. Struktura. Svojstva. Sintez. [Porphyrins. Structure. Properties. Synthesis.]. Moscow, 1985, pp. 175-204. (in Russ.)

6. Pavlov V.Ju., Ponomarev G.V. Himija geterociklicheskih soedinenij, 2004, no. 4, pp. 483-519. (in Russ.)

7. Mironov A.F. Uspehi himii porfirinov. [Russian Chemical porphyrins]. 2004, vol. 4, pp. 271-288. (in Russ.)

8. Berezin B.D. Izvestija vuzov. Himija i himich. tehnol, 1984, vol. 27, issue 3, pp. 259-271. (in Russ.)

9. Cannon J., Cannon M. Dye plants and dyeing. London: Herbert press, 1994. 128 p.

10. Svec W.A. The porphyrins. New-York: Acad. Press, 1978, vol. 5, pp. 342-400.

11. Belyh D.V. Novye podhody v sinteze polifunkcional'nyh hlorinov na osnove hlorofilla $a$. [New approaches in the synthesis of multifunctional chlorins based on chlorophyll $a$ ]. Doctor chemistry thesis. Ivanovo, 2012, 320 p. (in Russ.)

12. Berezin M.B. Sol'vatacija hlorofilla i rodstvennyh soedinenij. [Solvation of chlorophyll and related compounds]. Doctor chemistry thesis. Ivanovo, 1993, 340 p. (in Russ.)

13. Salgado A. Chlorin photosensitisers for tumor phototherapy. London: QMWC, 1993, $168 \mathrm{p}$.

14. Ashmarov V.V., Baum R.F., Meshherjakova A.L., Ponomarev G.V., Suhin G.M. Tezisy VII Mezhdunarodnoj konferencii po himii porfirinov $i$ ih analogov. [Abstracts of the VII International Conference on Chemistry of Porphyrins and their analogues]. St. Petersburg, 1995, pp. 151-152. (in Russ.)

15. Rashidova S.T. Pererabotka hlorofilla iz vydelenij tutovogo shelkoprjada na metalloporfiriny $i$ issledovanie ih fizikohimicheskih svojstv. [Processing of chlorophyll from silkworm excreta on metalloporphyrins and the study of their physical and chemical properties]. Candidate of chemical sciences thesis. Ivanovo, 1983, 135 p. (in Russ.)

16. Porra R.J. Biochim. Biophys. Acta., 1990, vol. 1015, no. 3, pp. 493-502.

17. Humphrey A.M. Food Chem., 1980, vol. 5, pp. 57-67.

18. Bruinsma J. Photochem. Photobiol., 1963, vol. 2, pp. 241-244.

19. Osuka A., Wada U., Shinoda S. Tetrahedron, 1996, vol. 52, no. 12, pp. 4311-4326.

20. Holden M. In: Chemistry and biochemistry of plant pigments. Ed by Goodwin T.W., New-York: Acad. Press., 1976, vol. 2, 2nd ed., pp. 1-27.

21. Borovcov V.V, Gribcov A.A., Kozyrev A.N., Brandis A.S., Ishida A., Sacata Y. Bull. Chem. Soc. Japan, 1992, vol. 65, pp. 1533-1537.

22. Ma L., Dolphin D. Tetrahedron, 1996, vol. 52, no. 3, pp. 849-860.

Received December 3, 2013

\footnotetext{
* Corresponding author.
} 